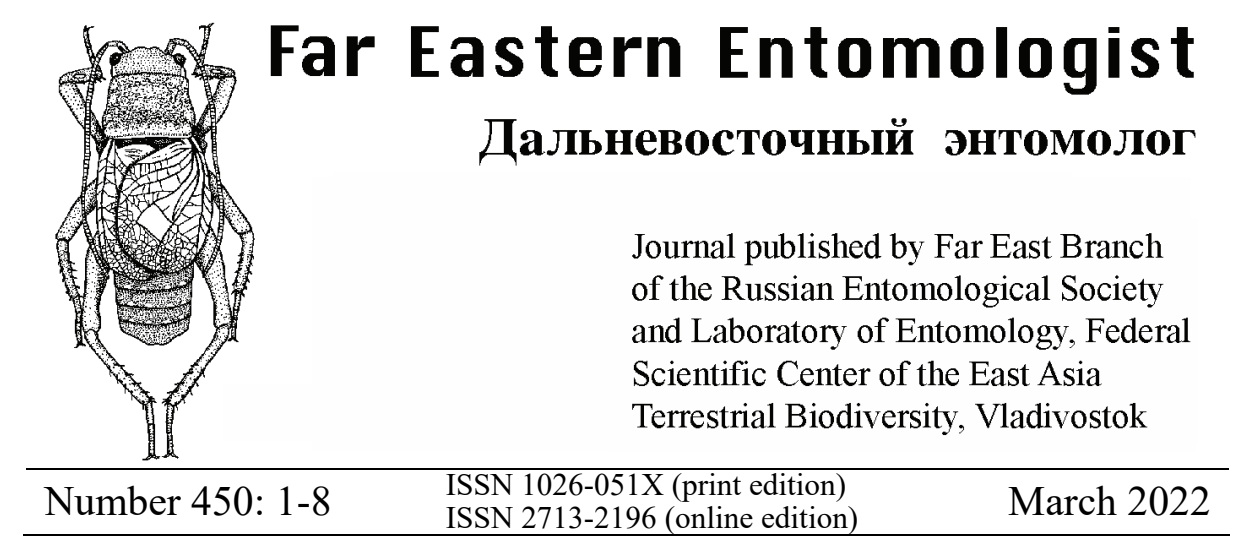

https://doi.org/10.25221/fee.450.1

http://zoobank.org/References/E68F3CCD-56AE-482C-B00D-3DC00695E2C4

\title{
A NEW SPECIES OF THE GENUS EPIDAMAEUS \\ BULANOVA-ZACHVATKINA, 1957 (ACARI: ORIBATIDA: DAMAEIDAE) FROM WESTERN SIBERIA
}

\section{S. G. Ermilov*, V. M. Salavatulin}

Institute of Environmental and Agricultural Biology (X-BIO), Tyumen State University, 10 Semakova Str., Tyumen 625003, Russia. *Corresponding author, E-mail:ermilovacari@yandex.ru

Summary. Epidamaeus hexatuberculatus sp. n. (Oribatida: Damaeidae) is described from Russia. The new species is similar to E. nortoni Bayartogtokh, 2004 and E. tritylos Behan-Pelletier et Norton, 1983 but differs from both by the absence of enantiophyses $E 2$ and $V$, the presence of mediosejugal enantiophysis, narrowly phylliform interlamellar seta and tubercle-like, rounded distally discidium, and the localization of prodorsobasal tubercle $D a$.

Key words: oribatid mites, taxonomy, morphology, Russia, Palaearctic region.

С. Г. Ермилов, В. М. Салаватулин. Новый вид рода Epidamaeus Bulanova-Zachvatkina, 1957 (Acari: Oribatida: Damaeidae) из Западной Сибири // Дальневосточный энтомолог. 2022. N 450. С. 1-8.

Резюме. Из России описан новый вид Epidamaeus (Oribatida: Damaeidae). Epidamaeus hexatuberculatus sp. n. Новый вид близок к E. nortoni Bayartogtokh, 2004 и E. tritylos Behan-Pelletier et Norton, 1983, но отличается от обоих видов отсутствием энантиофизисов $E 2$ и $V$, присутствием медиосеюгального энантиофизиса, узколистовидной межламеллярной щетинки и туберкуловидного, закругленного дистально дисцидия, и локализацией продорсобазальной туберкулы $D a$. 


\section{INTRODUCTION}

The oribatid mite genus Epidamaeus was proposed by Bulanova-Zachvatkina (1957) with Oribata bituberculata Kulczynski, 1902 as type species. At present, the genus comprises about 80 named species, collectively distributed mostly in the Holarctic region, but with some representation in the Neotropical and Oriental regions (Subías 2004, online version 2021; Norton \& Ermilov 2021). The generic traits were summarized and discussed by Bulanova-Zachvatkina (1957, 1975), Miko (2006) and Norton \& Ermilov (2021). The identification keys to some species of Epidamaeus were presented by Bulanova-Zachvatkina (1975), Miko (2006), Bayartogtokh (2010) and Norton \& Ermilov (2021).

During taxonomic identification of Epidamaeus from the Russian Western Siberia, we found one new species. The main goal of this paper is to describe and illustrate this species.

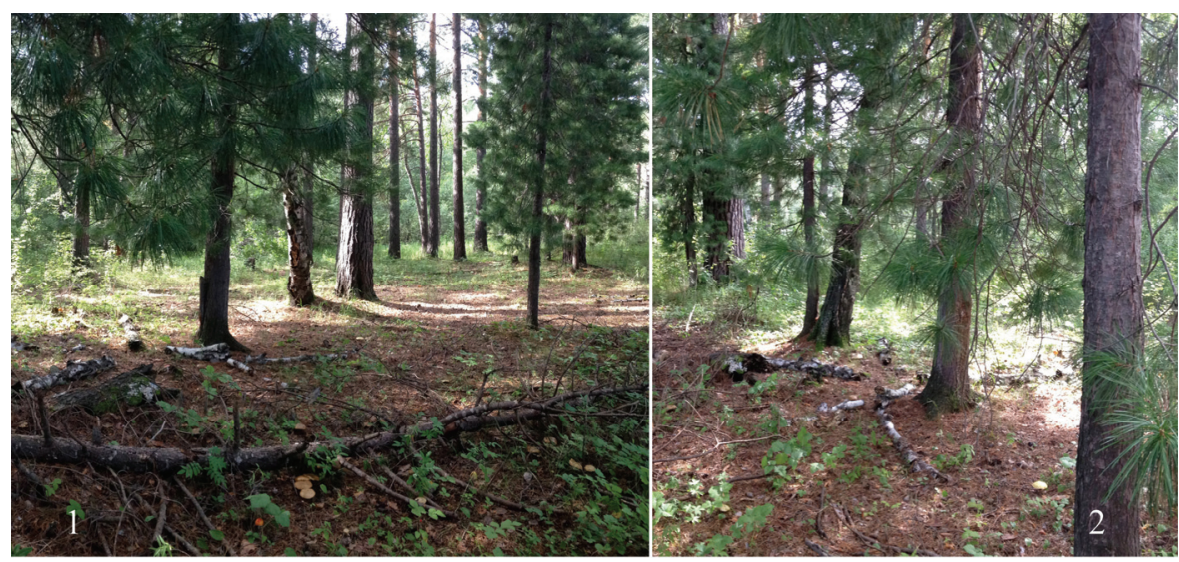

Figs 1, 2. Gathering place (Russia, Western Siberia, Tyumen Region, Tobolsk District, nearly Nadtsy Settlement, mixed forest) of Epidamaeus hexatuberculatus $\mathbf{s p .} \mathbf{n}$.

\section{MATERIAL AND METHODS}

Several samples $\left(250 \mathrm{~cm}^{3}\right.$ each) of litter and soil from mixed forest (Fig. 1) were collected by knife and a small shovel. Mites were extracted into $75 \%$ ethanol using Berlese's funnels (without electric lamps) during seven days in the laboratory. Specimens were mounted in lactic acid on temporary cavity slides for measurement and illustration. Body length was measured in lateral view, from the tip of the rostrum to the posterior edge of the gastronotum. Notogastral width refers to the maximum width of the notogaster in dorsal view. Lengths of body setae were measured perpendicular to their long axis, accounting for curvature. All body measurements are presented in micrometers. Formulas for leg setation are given in parentheses according to the sequence trochanter-femur-genu-tibia-tarsus (famulus included). Formulas for leg solenidia are given in square brackets according to the sequence genu-tibia-tarsus. 
Drawings were made with a camera lucida using a Leica transmission light microscope "Leica DM 2500". Morphological terminology used in this paper follows that of F. Grandjean: see Travé \& Vachon (1975) for references, Norton (1977) for leg setal nomenclature, Norton \& Behan-Pelletier (2009) and Norton \& Ermilov (2021), for overview.

The following morphological abbreviations are used: Prodorsum: ro, le, in, $b s$, $e x=$ rostral, lamellar, interlamellar, bothridial, and exobothridial seta, respectively; exv $=$ alveolar vestige of second exobothridial seta; $D a, B a, B a=$ prodorsobasal tubercles; $a b r=$ anterobothridial ridge. Notogaster: $c, l a, l m, l p, h, p=$ setae; s.a. $=$ spina adnata; $i a, i m, i p, i h$, ips = lyrifissures; gla $=$ opisthonotal gland opening. Epimeral and lateral podosomal regions: $e p=$ epimeral pit; $1 a, 1 b, 1 c, 2 a, 3 a, 3 b$, $3 c, 4 a, 4 b, 4 c, 4 d=$ setae; $M a, M p=$ mediosejugal tubercles; $S a, S p=$ parastigmatic tubercles; dis = discidium. Anogenital region: $g, a g, a n, a d=$ genital, aggenital, anal and adanal setae, respectively; $i a d=$ adanal lyrifissure. Legs: $\mathrm{Tr}, \mathrm{Fe}, \mathrm{Ge}, \mathrm{Ti}$, $T a=$ leg trochanter, femur, genu, tibia, and tarsus, respectively; $p . a$. $=$ porose area; $\omega, \varphi, \sigma=$ solenidia; $\varepsilon=$ famulus; $d, l, v, b v, e v, f t, t c, i t, p, u, a, s, p v, p l=$ setae.

\section{DESCRIPTION OF NEW SPECIES}

Epidamaeus hexatuberculatus Ermilov et Salavatulin, sp. n. http://zoobank.org/NomenclaturalActs/AB12E495-A525-4F71-93C4-4EECB7062682 Figs 3-9

TYPE MATERIAL. Holotype - + , Russia: Western Siberia, Tyumen Region, Tobolsk District, nearly Nadtsy Settlement, $58.631796^{\circ} \mathrm{N}, 68.566218^{\circ} \mathrm{E}$, soil-litter in mixed forest (birch-pine-cedar), 30.VII 2015, collected by V.M. Salavatulin. Paratypes: the same label as holotype, 1§ึ, 2ᄋ; Russia: Western Siberia, KhantyMansiysk Autonomous Region, Nephteyugansk District, nearly Kut-Yakh Settlement, $60.351376^{\circ} \mathrm{N}, 72.099673^{\circ} \mathrm{E}$, soil-litter in mixed forest (spruce-birch-cedar), 23.VII 2015, $2 \hat{\jmath}$, + , collected by V.M. Salavatulin.

TYPE DEPOSITION. The holotype is deposited in the collection of the Senckenberg Museum of Natural History, Görlitz, Germany; seven paratypes are deposited in the collection of the Tyumen State University Museum of Zoology, Tyumen, Russia. All specimens are preserved in $70 \%$ solution of ethanol with a drop of glycerol.

DIAGNOSIS. Body length: 531-630. Cerotegument filamentous. Exuvial scalps usually present on notogaster. Propodolateral apophysis absent. Three pairs of simple prodorsobasal tubercles $(D a, B a, B p) ; D a$ located anteromedial to $B a$. Rostral and lamellar setae setiform, barbed. Interlamellar seta narrowly phylliform. Bothridial seta rod-like, barbed. Spina adnata of medium length, thorn-like. Notogastral setae of $c$-, $l$ - and $h$-series phylliform, $p_{1}, p_{2}$ and $p_{3}$ setiform, barbed. Ventral enantiophyses $E 2$ and $V$ absent; mediosejugal enantiophysis well-developed. Parastigmatic tubercle $S a$ long, thorn-like, $S p$ tubercle-like. Epimeral setal formula: 3-1-3-4. Epimeral and anogenital setae setiform, slightly barbed. Discidium tubercle-like. Legs 
I and IV longer than body length; leg IV longest. Formulas of leg segments (I-IV): femur 7-6-4-4; genu and tibia 4-4-3-3; tarsus 21-18-18-15. Seta $v_{2}$ ' present on all tarsi.

DESCRIPTION. Measurements. Body length: 581 (holotype), 498 (male paratypes); 531-630 (female paratypes); notogaster width: 381 (holotype), 315-332 (male paratypes); 332-381 (female paratypes).

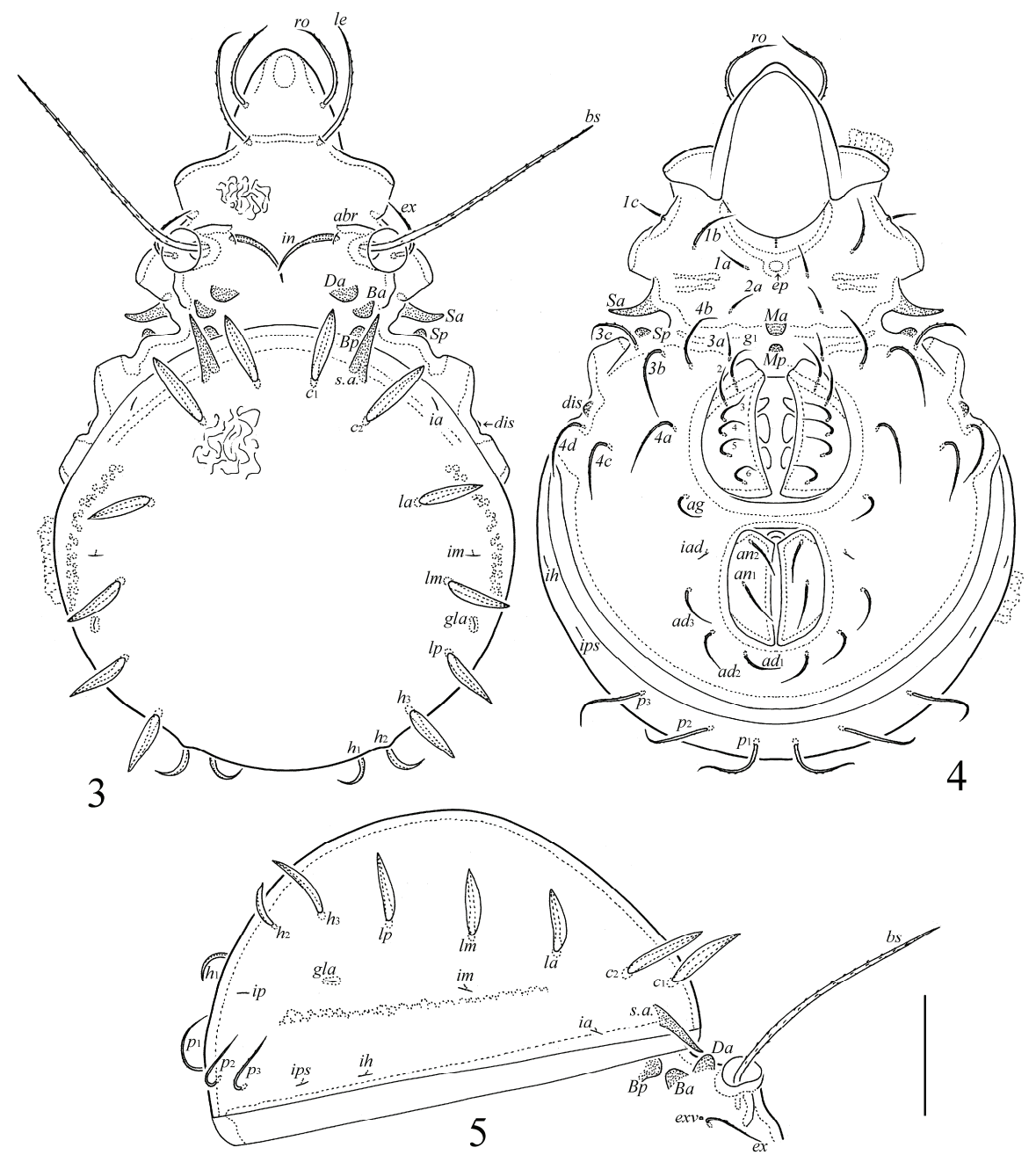

Figs 3-5. Epidamaeus hexatuberculatus sp. n., adult: 3 - dorsal view (legs not shown); 4 - ventral view (gnathosoma and legs not shown); 5 - notogaster and basal part of prodorsum, lateral view. Scale bar $100 \mu \mathrm{m}$. 


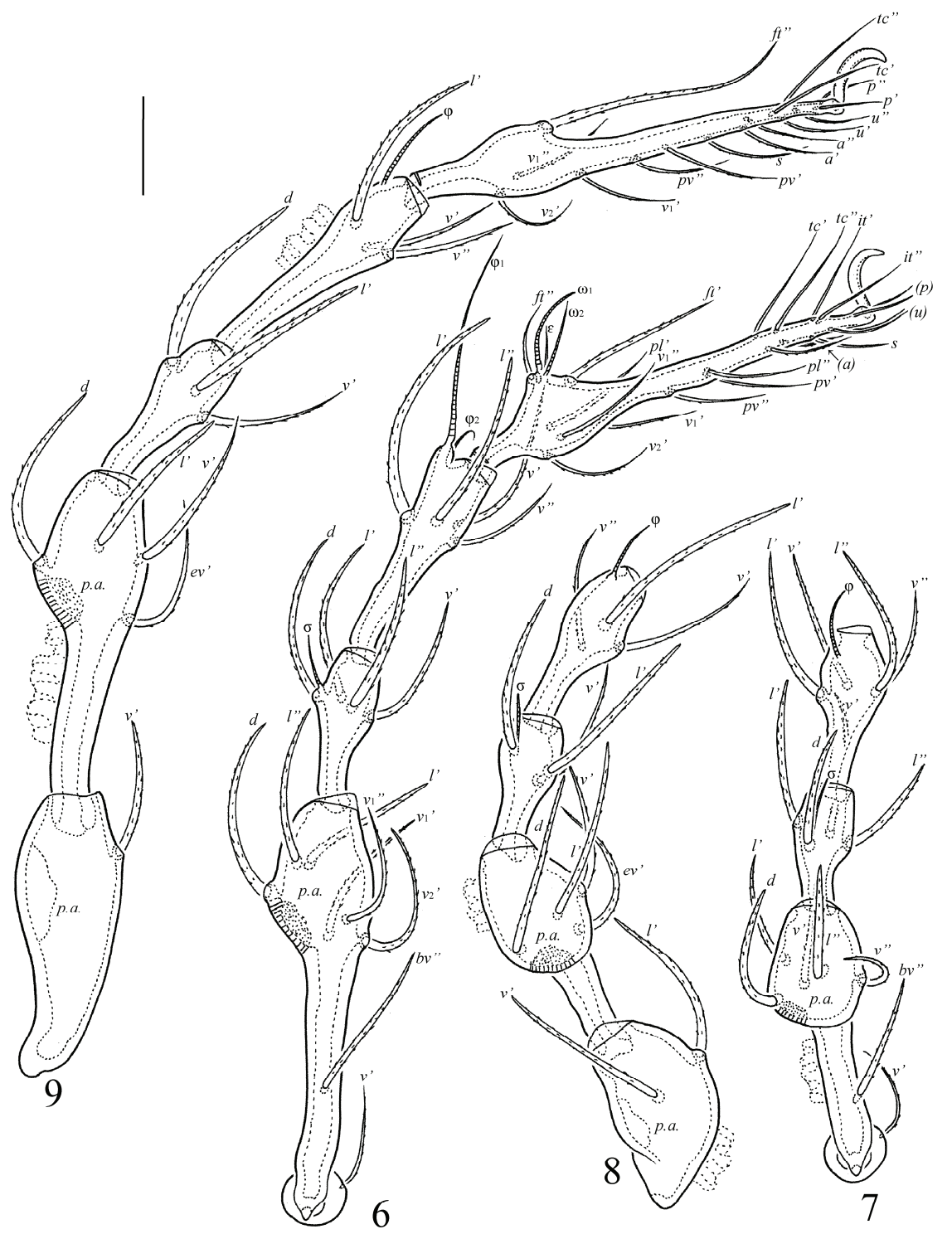

Figs 6-9. Epidamaeus hexatuberculatus sp. n., adult: 6 - leg I, right, antiaxial view; 7 leg II, without tarsus, right, dorsoantiaxial view; 8 - leg III, without tarsus, trochanter turned, left, antiaxial view; 9 - leg IV, left, antiaxial view. Scale bar $50 \mu \mathrm{m}$. 
Integument. Color medium to dark brown in preserved mature adults. Cerotegument conspicuous, excrescences varying in length but mostly filamentous on body and legs; setae usually without cerotegument. Procuticle mostly smooth. Usually with full stack of juvenile exuvial scalps, often with other adherent structures, particularly eggs or eggshells and fecal pellets, but without compacted organic debris.

Prodorsum. Rostrum rounded. Propodolateral apophysis absent. Prodorsobasal tubercle $D a$ and postbothridial enantiophysis $(B a, B p)$ well developed, subconical, distally rounded, similar in size; $D a$ located clearly anteromedial to $B a$; laterosejugal enantiophysis absent. Rostral (77-82) and lamellar (102-106) setae setiform, barbed; le thicker than ro. Indistinct transverse furrow between insertions of lamellar setae. Interlamellar seta (69-73) narrowly phylliform, directed mediad or posteromediad. Bothridial seta (221-225) rod-like, barbed. Bothridium with projecting part gobletshaped, with vertical banding; mutual distance of openings slightly greater than that of tubercles $B a$. Anterobothridial ridge present. Exobothridial seta (49-57) setiform, slightly barbed. Alveolar vestige of second exobothridial seta present posterior to seta $e x$.

Notogaster. Nearly circular in outline; uniformly curved, hemispherical with maximum height in middle. Spina adnata (41-53) shorter than a mutual distance of pair, thorn-like, directed anterolaterad, reaching or surpassing level of tubercle $\mathrm{Ba}$ (sometimes $D a$ ). Dorsal notogastral setae $(c-, l$ - and $h$-series) directed radially, inserted in uniformly curving, nearly semicircular row; $c_{1}, c_{2}$ (73-82) and $l a, l m, l p$, $h_{3}$ (57-61) relatively broadly phylliform, $h_{1}$ and $h_{2}$ (41-45) narrowly phylliform, $p_{1}$, $p_{2}$ and $p_{3}$ (57-61) setiform, barbed. Opisthonotal gland opening, notogastral lyrifissures $i a, i m, i p$, ih and ips and circumgastric sigillar band all distinct in transmitted light.

Gnathosoma. Typical for Epidamaeus (Norton \& Ermilov 2021). Subcapitulum size: $110-123 \times 73-77$. Subcapitular setae $(a: 28-32 ; m$ and $h: 49-53)$ setiform, slightly barbed. Adoral seta (12) setiform, straight, roughened. Palp (94-102) with

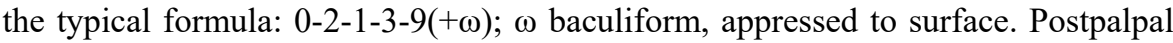
seta (8) spiniform, roughened. Chelicera (110-123) with two setiform setae; cha (41) barbed, $c h b$ (28) unilaterally ciliate in mediodistal part.

Epimeral and lateral podosomal regions. Tectum of podocephalic fossa normally developed, without lateral tooth-like projection. Medial coxisternal pit present on epimere I, shallow, with vaguely defined margins. Enantiophyses $E 2$ and $V$ are absent. Parastigmatic enantiophysis strongly dimorphic: $S a$ long, thorn-like; $S p$ tubercle-like, distally rounded, directed nearly perpendicular to $S a$. Mediosejugal enantiophysis distinct, just anterior to genital aperture; tubercles simple, $M a$ larger than $M p$. Epimeral setal formula: 3-1-3-4. All setae (1a, 2a, 3a: 32-36; 1c: 24-32; others: $57-61)$ setiform, slightly barbed; $1 c$ inserted on small but distinct tubercle; $3 c$ removed medially from tubercle $S p$ and acetabulum III. Discidium poorly developed, tubercle-like.

Anogenital region. Genital, aggenital, anal and adanal setae similar in length (4145), setiform, slightly barbed. Adanal lyrifissure oriented diagonally. 
Table 1. Leg mean lengths (micrometers) and their ratio to body mean length of one paratype Epidamaeus hexatuberculatus sp. $\mathrm{n}$.

\begin{tabular}{l|c|c|c|c|c|c|c}
\hline Leg & $\boldsymbol{T r}$ & $\boldsymbol{F e}$ & $\boldsymbol{G e}$ & $\boldsymbol{T i}$ & $\boldsymbol{T a}$ & All & Leg : body mean length \\
\hline I & 20 & 184 & 69 & 102 & 192 & 567 & 1.13 \\
\hline II & 20 & 139 & 61 & 82 & 164 & 466 & 0.93 \\
\hline III & 94 & 114 & 61 & 82 & 151 & 502 & 1.00 \\
\hline IV & 114 & 127 & 73 & 114 & 205 & 633 & 1.27 \\
\hline
\end{tabular}

Note: Basal part of each segment included in previous segment is not measured.

Legs. Leg III similar to body in length, leg II shorter than body length, legs I and IV longer than body length, leg IV longest; approximate length of leg segments shown in Table 1. Claw of each tarsus smooth. Porose area on femora I-IV and on trochanters III and IV distinctly visible. Formulas of leg setation and solenidia: I (17-4-4-21) [1-2-2], II (1-6-4-4-18) [1-1-2], III (2-4-3-3-18) [1-1-0], IV (1-4-3-3-15) [0-1-0]; homology of setae and solenidia indicated in Table 2. Solenidion on genua I-III shorter than coupled setae $d$. Famulus of tarsus I short, setiform, inserted between solenidia $\omega_{1}$ and $\omega_{2}$. Seta $v_{2}$ ' present on all tarsi.

Table. 2. Leg setation and solenidia of adult Epidamaeus hexatuberculatus sp. $\mathrm{n}$.

\begin{tabular}{l|l|l|l|l|l}
\hline Leg & $\boldsymbol{T r}$ & $\boldsymbol{F e}$ & $\boldsymbol{G e}$ & $\boldsymbol{T i}$ & $\boldsymbol{T a}$ \\
\hline I & $v^{\prime}$ & $\begin{array}{l}d,(l), b v^{\prime}, \\
\left(v_{1}\right), v_{2},\end{array}$ & $(l), v^{\prime}, d \sigma$ & $(l),(v), \varphi_{1}, \varphi_{2}$ & $\begin{array}{l}(f t),(t c),(i t),(p),(u),(a), s, \\
(p v),(p l),\left(v_{1}\right), v_{2}, \varepsilon, \omega_{1}, \omega_{2}\end{array}$ \\
\hline II & $v^{\prime}$ & $\begin{array}{l}d,(l), b v^{\prime}, \\
(v)\end{array}$ & $(l), v^{\prime}, d \sigma$ & $(l),(v), \varphi$ & $\begin{array}{l}(f t),(t c),(i t),(p),(u),(a), s, \\
(p v),\left(v_{1}\right), v_{2}, \omega_{1}, \omega_{2}\end{array}$ \\
\hline III & $l^{\prime}, v^{\prime}$ & $d, l^{\prime}, e v^{\prime}, v^{\prime}$ & $l^{\prime}, v^{\prime}, d \sigma$ & $l^{\prime},(v), \varphi$ & $\begin{array}{l}(f t),(t c),(i t),(p),(u),(a), s, \\
(p v),\left(v_{1}\right), v_{2},\end{array}$ \\
\hline IV & $v^{\prime}$ & $d, l^{\prime}, e v^{\prime}, v^{\prime}$ & $d, l^{\prime}, v^{\prime}$ & $l^{\prime},(v), \varphi$ & $\begin{array}{l}f t^{\prime},(t c),(p),(u),(a), s,(p v), \\
\left(v_{1}\right), v_{2},\end{array}$ \\
\hline
\end{tabular}

Note: Roman letters refer to normal setae, Greek letters to solenidia (except $\varepsilon=$ famulus), $d \sigma-$ seta and solenidion coupled. Single prime (') marks setae on the anterior and double prime (") setae on the posterior side of a given leg segment. Parentheses refer to a pair of setae.

ETYMOLOGY. The species name refers to the presence of six prodorsobasal tubercles (paired $D a, B a$ and $B p$ ).

REMARKS. Epidamaeus hexatuberculatus sp. n. is morphologically most similar to Epidamaeus nortoni Bayartogtokh, 2004 from Mongolia and E. tritylos Behan-Pelletier et Norton, 1983 from the Palaearctic region in having three pairs of prodorsobasal tubercles and phylliform dorsal notogastral setae. However, the new species differs from both by the absence ( $v s$. presence) of enantiophyses $E 2$ and $V$, the presence ( $v s$. absence) of mediosejugal enantiophysis, narrowly phylliform ( $v s$. setiform) interlamellar seta and tubercle-like, rounded distally ( $v s$. triangular, pointed distally) discidium, and the localization of prodorsobasal tubercle $D a$ (distinctly anteromedial to $B a v s$. medial to $B a$ ). Also, E. nortoni has four pairs ( $v s$. one pair) 
of setae on the epimere II and does not have a parastigmatic tubercle $S a$ (vs. well developed); E. tritylos has bacilliform ( $v s$. rod-like) bothridial seta.

\section{ACKNOWLEDGMENTS}

This research was supported by the cooperative agreement No. FEWZ-20210004 from the Russian Ministry of Science and Higher Education.

\section{REFERENCES}

Bayartogtokh, B. 2004. New damaeid mites (Acari: Oribatida) from Eastern Mongolia. Acarina, 12(1): 29-36.

Bayartogtokh, B. 2010. Oribatid mites of Mongolia (Acari: Oribatida). Moscow: KMK, 372 pp. [In Russian]

Behan-Pelletier, V.M. \& Norton, R.A. 1983. Epidamaeus (Acari: Damaeidae) of Arctic Western North America and extreme Northeast, U.S.S.R. The Canadian Entomologist, 115: 1253-1289. DOI: 10.4039/Ent1151253-10

Bulanova-Zachvatkina, E.M. 1957. Epidamaeus grandjeani Bul.-Zachv., gen. et sp. n. - a new oribatid mite from Kuril Islands (Acariformes, Oribatei). Entomologicheskoe Obozrenie, 36(2): 247-552. [In Russian]

Bulanova-Zachvatkina, E.M. 1975. Superfamily Belboidea. P. 120-143. In: Ghilyarov, M.S. (Ed.). Key to soil inhabiting mites. Sarcoptiformes. Nauka, Moscow. [In Russian]

Kulczynski, V. 1902. Species Oribatinarum (Oudms.) (Damaeinarum Michael) in Galicia collectae. Dissertationum mathematicarum et physicarum Academiae Litterarum Cracoviensis, Ser. B, 42: 10-56.

Miko, L. 2006. Damaeoidea Berlese, 1896. P. 179-207. In: Weigmann, G. (Ed.). Hornmilben (Oribatida). Die Tierwelt Deutschlands. Teil. 76. Keltern, Goecke and Evers.

Norton, R.A. \& Ermilov, S.G. 2021. Redescriptions of North American Epidamaeus (Acari, Oribatida, Damaeidae) species proposed by N. Banks, H.E. Ewing, A.P. Jacot, and J.W. Wilson. Zootaxa, 5021(1): 1-65. DOI: 10.11646/zootaxa.5021.1.1

Subías, L.S. 2004. Listado sistemático, sinonímico y biogeográfico de los Ácaros Oribátidos (Acariformes, Oribatida) del mundo (1758-2002). Graellsia, 60 (Número Extraordinario): $3-305$.

Subias, L.S. 2021. Listado sistemático, sinonímico y biogeográfico de los ácaros oribátidos (Acariformes: Oribatida) del mundo (Excepto fósiles) (16 actualización). Unpublished online update of Subias (2004). Available at: http://bba.bioucm.es/cont/docs/RO_1.pdf (Accessed March, 2021). 